\title{
A case of meningitis due to Listeria monocytogenes
}

\author{
A. BECK \\ From the Pathology Department, Paddington General Hospital, London
}

SYNOPSIS A case of meningitis due to Listeria monocytogenes is reported. The source and mode of infection could not be ascertained. The patient recovered after treatment with chlortetracycline.

Listeria monocytogenes was first described in 1926 as the cause of an epizootic in laboratory animals in Cambridge (Murray, Webb, and Swann, 1926). Although by 1958 approximately 500 human infections with this organism had been recorded (Seeliger, 1958) there are relatively few such reports from Great Britain. The following case of listerial meningitis is therefore presented.

\section{CASE REPORT}

H.T., an estate agent aged 39, was admitted on 22 June 1960 with a history of headache and vomiting for 12 hours. His temperature was $102^{\circ} \mathrm{F}$., he was drowsy, had neck rigidity and a positive Kernig's sign. Cerebrospinal fluid (C.S.F.) taken on admission was under pressure of $220 \mathrm{~mm}$. $\mathrm{H}_{2} \mathrm{O}$ and contained 66 cells per c.mm. (predominantly lymphocytes), $50 \mathrm{mg} . \%$ protein, and 62 $\mathrm{mg} . \%$ sugar. No organisms were seen in direct Gram and Ziehl-Neelsen films and cultures remained sterile. A blood count showed 21,200 white cells $(88 \%$ polymorphs, $11 \%$ lymphocytes, and $1 \%$ monocytes). The E.S.R. was $8 \mathrm{~mm}$. in one hour.

In view of the C.S.F. findings a presumptive diagnosis of virus meningitis was made and the initial treatment with six-hourly injections of 2 mega units of penicillin and six-hourly doses of $1.5 \mathrm{~g}$. sulphadiazine by mouth was discontinued after 24 hours. As the patient's drowsiness and pyrexia persisted a second C.S.F. specimen was taken on 28 June 1960 . It was under a pressure of 300 $\mathrm{mm}$. $\mathrm{H}_{2} \mathrm{O}$ and contained 217 cells per c.mm. $(75 \%$ lymphocytes and $25 \%$ polymorphs). Protein was 220 mg. \%, sugar $91 \mathrm{mg}$. \%, chlorides $562 \mathrm{mg}$. \%, and the Lange test was normal. Gram and Ziehl-Neelsen films were again negative, but a subculture of the C.S.F. grew a Gram-positive organism which was later identified as Listeria monocytogenes. A course of six-hourly chlortetracycline, $250 \mathrm{mg}$., was now started and under this treatment, which continued for two weeks, the patient's condition slowly improved. Pyrexia subsided within three days and neck stiffness and drowsiness gradually diminished. The white cell blood count which on 29 June had still been $16,000(82 \%$ polymorphs, $14 \%$ lymphocytes,

Received for publication 24 February 1961. and $4 \%$ monocytes) decreased by 21 July to $11,500(74 \%$ polymorphs, $1 \%$ eosinophils, $22 \%$ lymphocytes, and $3 \% \mathrm{~N}$ monocytes). A third specimen of C.S.F. on 17 July 1960 윽 still contained 153 cells per c.mm., $89 \%$ of which were $\overrightarrow{-}$ lymphocytes; protein was $140 \mathrm{mg}$. \%, sugar $67 \mathrm{mg} . \%, \mathbb{D}$ and chlorides $644 \mathrm{mg}$. \%. The Lange test gave a paretic type curve: 5554100000 . Cerebrospinal fluid and blood $\frac{\mathbb{D}}{3}$ Wassermann reactions were negative and culture of $\frac{\mathbb{D}}{-}$
C.S.F. remained sterile.

Specimens of C.S.F., faeces, and a throat swab sent to $\vec{\varphi}$ the Routine Diagnostic Laboratory, Colindale, for virus of isolation, and paired sera for routine virus complementfixation tests all gave a negative result.

The patient made a complete recovery and was discharged on 26 July 1960.

\section{DESCRIPTION OF PATIENT'S (HT) ORGANISM}

MORPHOLOGY AND CULTURAL CHARACTERISTICS The $\overline{\bar{o}}$ organism was a short, Gram-positive bacillus, $0.5 \times 1$ to $2 \mu$, occurring singly or in V-shaped or parallel pairs. It was motile when grown at room temperature. On horse blood agar it grew in small, smooth, transparent colonies, with an entire edge which after 48 hours attained a dia-? meter of 1 to $2 \mathrm{~mm}$.; the colonies were surrounded by $a \frac{\sigma}{3}$ narrow zone of faint haemolysis. It was sensitive to discs containing penicillin $(0.5$ units), streptomycin $(20 \mu \mathrm{g}$.$) , \varrho$ chloramphenicol (40 $\mu \mathrm{g}$.), tetracycline $(10 \mu \mathrm{g}$.), erythromycin (1 $\mu \mathrm{g}$.), oleandomycin $(2 \mu \mathrm{g}$.$) , ristocetin (25 \mu \mathrm{g}$.), 을 neomycin $(60 \mu \mathrm{g}$.$) , sulphafurazole (0 \cdot 1 \mathrm{mg}$.$) , and fura-$ dantin (10 mg.). It was resistant to novobiocin $(2 \mu \mathrm{g}$.) ando to neomycin $(30 \mu \mathrm{g}$. $)$.

BIOCHEMICAL CHARACTERISTICS The biochemical reactions were compared with those of a stock culture of Listeria monocytogenes (N.C.T.C. 7973) obtained from the National Collection of Type Cultures (Table I).

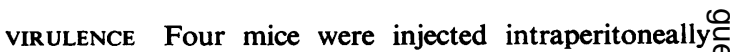
with $0.3 \mathrm{ml}$. of an overnight glucose broth culture diluted $1: 10$ of the patient's strain. A culture of tail blood of one of these mice taken 24 hours later yielded a profuse growth of the infecting organism. Three mice died, three $\frac{\overrightarrow{\mathbb{D}}}{\mathrm{D}}$ days, and the fourth one, six days after, the injection, $\stackrel{?}{\square}$ with evidence of septicaemia and slight peritonitis. In each of these, the organism was recovered from heart blood, 512 
TABLE I

BIOCHEMICAL REACTIONS OF CULTURES HT AND NCTC 7973

\begin{tabular}{|c|c|c|c|c|c|}
\hline $\begin{array}{l}\text { Fermentation } \\
\text { Reactions* }\end{array}$ & $H T$ & NCTC 7973 & Other Biochemical Tests & $H T$ & NCTC 7973 \\
\hline Arabinose & - & - & Methyl red & - & - \\
\hline Xylose & - & - & Voges-Proskauer & - & \pm \\
\hline Rhamnose & $+{ }^{2} \dagger$ & $t^{1}$ & Citrate utilization & - & - \\
\hline Glucose & $t^{1}$ & $t^{1}$ & Nitrate reduction & - & - \\
\hline Laevulose & $t^{1}$ & $t^{1}$ & Gelatine liquefaction & - & - \\
\hline Sucrose & $+^{\circ}$ & $+\cdots$ & $\mathrm{H}_{2} \mathrm{~S}$ production & - & - \\
\hline Maltose & $t^{2}$ & $t^{1}$ & Indole production & - & - \\
\hline Lactose & +4 & +3 & Urease production & - & - \\
\hline Trehalose & $t^{1}$ & $t^{1}$ & Growth on McConkey agar & + & + \\
\hline Raffinose & - & - & Growth on Hoyle's tellurite agar & + & + \\
\hline Dextrin & - & $++^{\prime}$ & Growth on $7 \%$ salt agar & + & + \\
\hline Inulin & - & - & & & \\
\hline Glycerol & $t^{2}$ & $\pm^{2}$ & & & \\
\hline Adonitol & +10 & - & & & \\
\hline Mannitol & - & - & & & \\
\hline Dulcitol & - & - & & & \\
\hline Sorbitol & - & +19 & & & \\
\hline Salicin & $t^{2}$ & $t^{2}$ & & & \\
\hline Aesculin & +1 & $t^{1}$ & & & \\
\hline Inositol & - & - & & & \\
\hline
\end{tabular}

*Acid without gas.

†Day on which fermentation was first observed.

liver, and spleen. Sections of liver revealed numerous scattered micro-abscesses with occasional central necrosis containing many small Gram-positive bacilli. Similar confluent abscesses containing masses of bacilli were seen in the spleen. The kidneys showed only a few minute foci of infiltration with polymorphs and macrophages in the cortex in which Gram-positive bacilli could be found. No changes were seen in the lungs except for a massive infiltration of the visceral pleura with Gram-positive bacilli.

The instillation of three drops of an overnight glucose broth culture into the conjunctival sac of a guinea-pig and a rabbit produced within 24 hours an intensive conjunctivitis which subsequently became purulent and was associated with dense corneal opacities.

A rabbit injected intravenously with $1 \mathrm{ml}$. of an overnight glucose broth culture diluted $1: 10$ died after seven days with evidence of septicaemia. Necropsy revealed a sero-fibrinous pericarditis and multiple small abscesses in the spleen. The infecting organism was recovered from lung, spleen, and pericardial fluid.

Two other rabbits were injected intravenously, each with $0.25 \mathrm{ml}$. of overnight glucose broth cultures diluted
$1: 10$ of the patient's organism (HT) and the type strain NCTC 7973, respectively. They survived and gave the blood counts shown in Table II.

The cells counted under the heading 'monocytes' showed a morphology which was intermediate between that of typical monocytes and large lymphocytes. They had a round, oval, or horseshoe-shaped nucleus of loose texture and abundant grayish blue cytoplasm. Both cultures produced the maximum monocyte response$25.5 \%$ with culture HT and $44.5 \%$ with culture NCTC 7973 - on the third day after injection.

SEROLOGY Antisera were prepared by repeated intravenous injection of rabbits with formolized suspensions of cultures HT and NCTC 7973. These suspensions were also used for agglutination tests which were read after two hours' incubation at $37^{\circ} \mathrm{C}$. and overnight stay at $4^{\circ} \mathrm{C}$. For absorption, sera were diluted $1: 25$; each serum was absorbed three times with the packed deposit of a heavy formolized suspension of the absorbing strain. Table III shows that each strain absorbed completely its autologous antibody and antibody reacting with the other

TABLE II

BLOOD COUNTS OF RABBITS INJECTED WITH CULTURES HT AND NCTC 7973

\begin{tabular}{|c|c|c|c|c|c|c|c|c|}
\hline \multirow{3}{*}{$\begin{array}{l}\text { Day after } \\
\text { Iniection }\end{array}$} & \multicolumn{8}{|c|}{ Rabbit Inoculated with } \\
\hline & \multicolumn{4}{|l|}{ Culture $H T$} & \multicolumn{4}{|c|}{ Culture NCTC 7973} \\
\hline & $\begin{array}{l}\text { Total } \\
\text { White Count }\end{array}$ & $\begin{array}{l}\text { Polymorphs } \\
(\%)\end{array}$ & $\begin{array}{l}\text { Lymphocytes } \\
(\%)\end{array}$ & $\begin{array}{l}\text { Monocytes } \\
(\%)\end{array}$ & $\begin{array}{l}\text { Total } \\
\text { White Count }\end{array}$ & $\begin{array}{l}\text { Polymorphs } \\
(\%)\end{array}$ & $\begin{array}{l}\text { Lymphocytes } \\
(\%)\end{array}$ & $\begin{array}{l}\text { Monocytes } \\
(\%)\end{array}$ \\
\hline Before & 9,000 & 33 & 63 & 4 & 5,700 & 68.5 & 26.5 & 5 \\
\hline 1 & 7,500 & 65 & 32 & 3 & 4,600 & 58 & 40 & 2 \\
\hline 2 & & & & & 4,800 & 58.5 & 30 & 11.5 \\
\hline 3 & 8,300 & 57 & $17 \cdot 5$ & 25.5 & 9,000 & $30 \cdot 5$ & 25 & 44.5 \\
\hline 4 & 9,400 & $65 \cdot 5$ & $17 \cdot 5$ & 17 & 5,000 & 38 & $34 \cdot 5$ & $27 \cdot 5$ \\
\hline 5 & 9,500 & 40.5 & $43 \cdot 5$ & 16 & & & & \\
\hline 6 & 9,400 & 53 & 27.5 & 19.5 & $\mathbf{7 , 4 0 0}$ & $40 \cdot 5$ & $27 \cdot 5$ & 32 \\
\hline 7 & 11.200 & 56 & 31 & 13 & 6,500 & $39 \cdot 5$ & 32.5 & 28 \\
\hline
\end{tabular}


strain, both from its own antiserum and from antiserum prepared with the other strain.

\section{TA B LE III}

ABSORPTION OF ANTISERA WITH CULTURES HT AND NCTC 7973

\begin{tabular}{llrr}
$\begin{array}{l}\text { Antiserum } \\
\text { against } \\
\text { Culture }\end{array}$ & Absorbing Antigen & \multicolumn{2}{c}{ Agglutinable Antigen } \\
\cline { 3 - 4 } & & $\begin{array}{l}\text { Culture } \\
\text { Culture }\end{array}$ & \multicolumn{2}{c}{ NCTC 7973 } \\
\hline HT & & 12,800 & 6,400 \\
& & 0 & 0 \\
NCTC 7973 & Culture HT & 0 & 0 \\
& Culture NCTC 7973 & 1,600 & 6,400 \\
& Culture HT & 0 & 0 \\
& Culture NCTC 7973 & 0 & 0
\end{tabular}

DISCUSSION

Except for the negative Voges-Proskauer reaction, the absence of late fermentation of dextrin and sorbitol, and the presence of late fermentation of adonitol, the biochemical reactions of the patient's organism were identical with those of the type strain of Listeria monocytogenes. Both cultures produced an increase of abnormal mononuclear cells in the blood of rabbits, and absorption tests on antisera prepared with them showed their close antigenic similarity. The virulence of the patient's organism for mice on intraperitoneal inoculation, and for rabbits and guinea-pigs on intra-ocular instillation, further confirmed the organism as Listeria monocytogenes.

Repeated examinations of the patient's serum during and after his illness failed to reveal any agglutinating antibodies against a formolized suspension of his own organism. This may have been due, as was pointed out by Seeliger (1958), to lack of antigenic stimulus as the result of antibiotic treatment.

The source and mode of infection of this patient are unknown. Listeriae have been found in more than 30 species of animals, including cattle, sheep, pigs, cats, dogs, and a variety of rodents and birds (Gray, 1958). There was no history of close contact with any of these animals. Nor did the patient remember having drunk any unpasteurized milk, which according to Dedië (1958) and de Vries and Strikwerda (1956), may contain this organism. The mode of infection with Listeriae remains in most cases obscure. There are only a few observations in which there is strong circumstantial evidence of transmission from animals to man. Ödegaard, Grelland, and Henriksen (1952) described a fatal case of listerial meningitis in a farmer who fell ill after cleaning a stable containing sheep infected with this organism. And van der Schaaf (1955) observed another farmer who developed fatal listerial menin- gitis after assisting an aborting cow from a herd in $\underline{\mathrm{o}}$ which cases of listerial encephalitis were subsequently $\vec{F}$ found.

Human listerial infection manifests itself in? various forms. The most frequent one is a septicaemic $\frac{\bar{\sigma}}{\bar{\rho}}$ condition of the foetus or newborn known as $\frac{\pi}{\sigma}$ granulomatosis infantiseptica which is responsible 2 for a proportion of spontaneous abortions and neonatal deaths. According to Potel (1958), who $\overrightarrow{0}$ investigated 247 bacteriologically proved cases of listeriosis, $75 \%$ belonged to this group. The second $\vec{\omega}$ most frequent manifestation is listerial meningitis or $?$ meningo-encephalitis which occurs in both infants? and adults; and the third one is the adenoid form $\vec{f}$ which presents as glandularfever. Except for one case $i r$ of this last type reported by Webb (1943), all $\stackrel{\text { or }}{ }$ listerial infections reported in Great Britain have ${ }^{N}$ been meningeal (Gibson, 1935; Wright and 5 McGregor, 1939; Mair, Mair, Stirk, and Reid, 1957; $\vec{\sim}$ Edmunds, Nicholson, and Douglas, 1957; Barrow $\mathbb{D}$ and Pugh, 1958; Turner, Dawson, and Pryce-Jones, $\frac{\mathrm{T}}{\Phi}$ 1958; Moore and Whitmore, 1960). It is possible $\frac{1}{3}$ that infections with this organism are more frequent $\stackrel{\Phi}{\Phi}$ than is generally supposed. Since the completion of this investigation five more cases of meningeal $\stackrel{\circ}{\circ}$ infection have been recorded in the weekly reports. of the Public Health Laboratory Service (McDonald, 1961). In view of the above-mentioned frequency of neonatal listeriosis it is likely that systematic bacteriological investigation of neonatal deaths would reveal $\cong$ further instances of this infection in Great Britain.

I wish to thank Dr. R. Green for permission to quote from the case history, Professor R. A. Webb for confirmation of the bacteriological diagnosis, Dr. J. C. McDonald for data from the weekly reports of the Public Health Laboratory Service, and Mr. O. Stout for technical assistance.

\section{REFERENCES}

Barrow, G. I., and Pugh, R. J. (1958). J. Path. Bact., 75, 9.

Dedië, K. (1958). Zbl. Vet.-Med. Beiheft 1, p. 99.

Edmunds, P. N., Nicholson, D. N., and Douglas, D. M. (1957). Brit. med. J., 2, 188.

Gibson, H. J. (1935). J. Path. Bact., 41, 239.

Gray, M. L. (1958). Zbl. Vet.-Med. Beiheft 1, p. 90.
Mair, Helène, J., Mair, N. S., Stirk, E. M., and Reid, A. W. (1957). J. clin. Path., 10, 231.

McDonald, J. C. (1961). Personal communication.

Moore, S., and Whitmore, D. N. (1960). Brit. med. J., 2, 1572.

Murray, E. G. D., Webb, R. A., and Swann, M. B. R. (1926). J. Path. Bact., 29, 407.

Odegaard, B., Grelland, R., and Henriksen, S. D. (1952). Acta med. scand., 142, 231.

Potel, J. (1958). Zbl. Vet.-Med. Beiheft 1, p. 70.

Schaaf, A. van der (1955). Ned. T. Geneesk., 99, 2855.

Seeliger, H. P. R. (1958). Zbl. Vet.-Med. Beiheft 1, p. 20.

Turner, G. C. Dawson, I. M. P., and Pryce-Jones, Elizabeth (1958) J. clin. Path., 11, 266.

Vries, J. de, and Strikwerda, R. (1956). Zbl. Bact., I Abt. Orig., 167, 229.

Webb, R.A. (1943). Lancet, 2, 5.

Wright, Helen A., and McGregor, Agnes R. (1939). J. Path. Bact. 48, 470 .

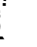

